\title{
Development of Real-Time and Conventional PCR Assays for Identifying Stubby Root Nematode Paratrichodorus allius
}

Danqiong Huang and Guiping Yan, North Dakota State University, Department of Plant Pathology, Fargo 58102; and Andrea M. Skantar, United States Department of Agriculture-Agricultural Research Service, Nematology Laboratory, Beltsville, MD 20705

\begin{abstract}
Paratrichodorus allius is an important pest on many crops, particularly on potato due to its ability to transmit Tobacco rattle virus causing corky ringspot disease on tubers. Detection and identification of $P$. allius are important for effective disease management. In this study, a rapid and reliable molecular diagnosis of this nematode targeting internal transcribed spacer ribosomal DNA was established. The specificity of the designed primers was evaluated using 29 nematode species and results showed that a single amplicon was produced from DNA of $P$. allius only. Detection sensitivity analysis indicated that a $9.6 \times 10^{-4} \mathrm{ng}$ of DNA template could be detected by conventional PCR and $1.92 \times 10^{-4} \mathrm{ng}$ of DNA by real-

time PCR. The PCR assays amplified DNA of stubby root nematodes isolated from 18 soil samples in North Dakota and Minnesota, which were confirmed as $P$. allius by sequencing. Both conventional PCR and realtime PCR assays amplified target nematodes from complex nematode communities, supporting the success of this molecular diagnosis of $P$. allius. This is the first report of $P$. allius identification using the real-time PCR method and from nematode communities with other nematodes using conventional PCR. The new PCR assays provide rapid species identification and are suitable for use in diagnostic laboratories and detection of field infestations with $P$. allius.
\end{abstract}

Stubby root nematodes are migratory ectoparasitic nematodes attacking plants and are so named based on the symptoms of stunted or stubby appearance of the root system in infected plants. They belong to the family Trichodoridae, comprising over 100 species that can be divided into five genera, including Trichodorus Cobb, 1913; Paratrichodorus Siddiqi, 1974; Monotrichodorus Andrassy, 1976; Allotrichodorus Rodriguez-M, Sher and Siddiqi, 1978; and Ecuadorus Siddiqi, 2002 (Decraemer and Robbins 2007). Among them, Trichodorus and Paratrichodorus are the largest genera and are distributed worldwide (Decraemer and Robbins 2007). Thirteen stubby root nematodes species are known to vector tobraviruses, consisting of four Trichodorus spp. (Trichodorus primitivus, T. similis, T. cylindricus, and T. viruliferus) and nine Paratrichodorus spp. ( $P$. anemones, $P$. divergens, $P$. hispanus, $P$. nanus, $P$. pachydermus, $P$. teres, $P$. tunisiensis, $P$. allius, $P$. minor, and $P$. porosus) (Decraemer and Robbins 2007; Ploeg and Decraemer 1997). Nine of them cause economically important disease in potato (Riga et al. 2007). It was found that $P$. allius was the most prevalent vector of Tobacco rattle virus (TRV) causing corky ringspot disease of potato, which produced internal and external tuber symptoms and consequently reduced the quality of potato tubers (Mojtahedi and Santo 1999; Riga et al. 2007). Viruliferous stubby root nematodes can efficiently transmit the virus to healthy plants. For example, the infection of TRV on wild tobacco occurred within 4 days after inoculation with a single T. pachydermus carrying virus (Decraemer 1995; Van Hoof 1964). That could explain why the low density of stubby root nematodes normally present in the field still caused severe disease on crops such as potato (Ingham et al. 2000).

Management of stubby root nematodes can be achieved by applying chemical nematicides, using resistant or tolerant cultivars, and planting nonsusceptible crops on infested land. Consequently, it is very important to detect and quantify the presence of virus vector nematodes prior to planting so that growers can make planting decisions and consider the strategies for nematode control. Taxonomic identification of stubby root nematodes based on morphological features is complex, time consuming, and skill based due to minor

Corresponding author: G. P. Yan; E-mail: guiping.yan@ ndsu.edu

Accepted for publication 17 January 2017.

() 2017 The American Phytopathological Society differences among closely related species (Decraemer and Baujard 1998). Therefore, DNA-based methods for stubby root nematode species identification have been developed, according to the variability in the sequence of ribosomal DNA (rDNA), mainly $18 \mathrm{~S}$, internal transcribed spacer (ITS), and the D2-D3 region of 28S rDNA (Boutsika et al. 2004a,b; Duarte et al. 2011; Holeva et al. 2006; Kumari and Subbotin 2012; Riga et al. 2007). For species identification, Boutsika et al. (2004b) developed a species-specific polymerase chain reaction (PCR) for differentiation of four stubby root nematodes (P. macrostylus, P. pachydermus, $T$. primitivus, and T. similis) using a pair of primers consisting of forward universal primers located in $18 \mathrm{~S}$ rDNA and reverse-specific primers located in ITS1 rDNA. Riga et al. (2007) also reported a PCR method with species-specific primers designed from ITS1 rDNA to identify two stubby root nematodes, $P$. allius and $P$. teres. Apart from direct PCR methods, PCR restriction fragment length polymorphism (RFLP) is also a useful method for identification of stubby root nematodes. Duarte et al. (2011) effectively identified 12 stubby root nematode species using a PCR-RFLP assay based on the 18S rDNA. Kumari and Subbotin (2012) generated PCR-RFLP profiles of 18S rDNA and the D2-D3 region of 28S rDNA, which could distinguish 33 and 19 stubby root nematode species, respectively. Compared with a conventional PCR assay, a real-time PCR assay has the advantages of more specificity, higher detection sensitivity, and the ability to perform nematode DNA quantification, which provides more information on nematode diagnosis. However, research on the identification and quantification of stubby root nematodes is very limited. Holeva et al. (2006) described a method for quantification of DNA from two stubby root nematodes ( $P$. pachydermus and $T$. similis) using realtime PCR (TaqMan) with primer and probe sets derived from $18 \mathrm{~S}$ rDNA. Until now, no study has been reported regarding the detection of $P$. allius using real-time PCR.

Previously, our surveys conducted in 2014 found stubby root nematodes on many field crops such as soybean, barley, potato, and sugarbeet in North Dakota and Minnesota (Yan et al. 2015, 2016a,b). Combination of morphological features and sequencing information demonstrated that the species of stubby root nematodes found in a sugarbeet field in Minnesota and a potato field in North Dakota was $P$. allius (Yan et al. 2016a,b). Using the primer set (BL18/PAR2) designed by Riga et al. (2007), a single 432-bp fragment was amplified from $P$. allius as expected. However, other nematodes such as pin nematodes (Paratylenchus spp.) and spiral nematodes (Helicotylenchus spp.) commonly existing in North Dakota also yielded the same amplification pattern as $P$. allius (data not shown). In addition, the amplified 
PCR fragment (432 bp) is longer than optimal (usually less than $300 \mathrm{bp}$ ) for a real-time PCR assay, making this published pair of primers unsuitable for detecting and identifying $P$. allius nematodes. Therefore, in order to detect and distinguish $P$. allius from other nematodes present in the same nematode community or in the same field, new species-specific primers need to be exploited for molecular diagnosis of $P$. allius. The objective of this study was to develop conventional and real-time PCR assays with designed species-specific primers for reliable and sensitive detection and amplification of $P$. allius DNA from single nematodes and from mixed nematode communities extracted from various infested fields. This study will provide new molecular diagnostic assays as an alternative to visually identifying the presence of this nematode species based on morphology.

\section{Materials and Methods}

Nematode collection, extraction, and counting. Stubby root nematode $P$. allius was previously found and identified in a potato field in Sargent County, ND and a sugarbeet field in Clay County, MN (Yan et al. 2016a,b). In this study, 27 soil samples were collected from fields cultivated with various crops in North Dakota and Minnesota, including 18 samples in Table 1 (F1 to F18) and nine samples in Table 2 (communities 1 to 7, 12, and 13). Vermiform nematodes were extracted from $200 \mathrm{~g}$ of soil using sieving and a sucrose-centrifugation method (Jenkins 1964; Plaisance and Yan 2015) and resuspended in $20 \mathrm{ml}$ of distilled water. The presence of stubby root nematodes was identified by key morphological features under a dissecting microscope (Zeiss Stemi 305 lab microscope; Zeiss, Thornwood, NY), for instance, solid and curved onchiostyle and cigar-shaped body (Decraemer and Baujard 1998). To estimate the number of stubby root nematodes, a 1-ml aliquot of nematode suspension was placed on a nematode counting slide and then target nematodes were counted, as described by Plaisance and Yan (2015). The densities of target nematodes were expressed as the number of target nematodes per $200 \mathrm{~g}$ of soil. Subsequently, stubby root nematodes were hand picked under a dissecting microscope for molecular analysis.

DNA extraction. Proteinase K method was used for DNA extraction from individual nematodes, as described by Kumari and Subbotin (2012). The final $20 \mu \mathrm{l}$ of DNA suspension was stored at $-20^{\circ} \mathrm{C}$ until use for the subsequent experiments. All 18 DNA samples in Table 1 and 16 DNA samples in Table 3 (samples 1 to 7, 13, 29, 32, and 37 to 42) were extracted in our lab. Each DNA sample was extracted from three nematode individuals independently as biological replicates. The 26 DNA samples of nematode species used as controls were obtained from the United States Department of Agriculture-Agricultural Research Service Nematology Laboratory (Beltsville, MD) (samples 8 to 10,14 to $28,31,33,35$, and 36) and Oregon State University for primer specificity evaluation (samples $11,12,30$, and 34) (Table 3 ).

For DNA extraction from a nematode community (Table 2, communities 1 to 7), a modified phenol-chloroform-isoamyl alcohol (PCI) method was performed, as described by Donn et al. (2008) and Fatima et al. (2011). In detail, nematodes were extracted from $200 \mathrm{~g}$ of soil and collected in approximately $300 \mu \mathrm{l}$ of water after centrifugation at 12,000 rpm (Sorvall Legend Micro 17 Microcentrifuge; Thermo Scientific, Hudson, $\mathrm{NH}$ ) for $10 \mathrm{~min}$ at room temperature. Then, $500 \mu \mathrm{l}$ of worm lysis solution (1\% sodium dodecyl sulfate, $50 \mathrm{mM}$ EDTA, $100 \mathrm{mM} \mathrm{NaCl}$, proteinase $\mathrm{K}$ at $100 \mu \mathrm{g} / \mathrm{ml}, 1 \%$ 2-mercaptoethanol, and $100 \mathrm{mM}$ Tris- $\mathrm{HCl} \mathrm{pH}, 8.5$ ) was added to the nematode suspension. After being frozen at $-20^{\circ} \mathrm{C}$ for $20 \mathrm{~min}$, the mixtures were thawed and

Table 1. Species identification of stubby root nematodes (SRN) from 18 fields with five crops in North Dakota and Minnesota, using a conventional polymerase chain reaction (PCR) assay (Conv), real-time PCR assay (RT), and DNA sequencing

\begin{tabular}{|c|c|c|c|c|c|c|c|c|}
\hline \multirow[b]{2}{*}{ Field $^{\mathbf{a}}$} & \multirow[b]{2}{*}{ Current crop } & \multirow[b]{2}{*}{ County, state } & \multirow[b]{2}{*}{ Sampling date } & \multirow[b]{2}{*}{$\mathbf{S R N}^{\mathbf{b}}$} & \multicolumn{2}{|c|}{ PCR assay } & \multirow[b]{2}{*}{ Species $^{\mathrm{e}}$} & \multirow[b]{2}{*}{ GenBank $^{\mathbf{f}}$} \\
\hline & & & & & Conv $^{c}$ & RT $(\mathbf{C q})^{\mathbf{d}}$ & & \\
\hline F1 & Sugarbeet & Clay, MN & $06 / 25 / 2015$ & 20 & + & $24.2 \pm 0.0$ & P. allius & KX901757, KX901771 \\
\hline F2 & Sugarbeet & Clay, MN & $09 / 04 / 2015$ & 200 & + & $26.8 \pm 0.1$ & P. allius & KX901758, KX901772 \\
\hline F3 & Sugarbeet & Clay, MN & 09/01/2015 & 80 & + & $24.2 \pm 0.0$ & P. allius & KX901759, KX901773 \\
\hline F4 & Field pea & Mountrail, ND & $10 / 09 / 2015$ & 20 & + & $22.9 \pm 0.2$ & P. allius & KX901760, KX901774 \\
\hline F5 & Corn & Foster, ND & $10 / 14 / 2015$ & 25 & + & $24.9 \pm 0.5$ & P. allius & KX901761, KX901775 \\
\hline F6* & Soybean & Richland, ND & $05 / 23 / 2015$ & 30 & + & $18.9 \pm 0.0$ & P. allius & KX901762,... \\
\hline F7 & Soybean & Sargent, ND & $10 / 02 / 2015$ & 40 & + & $27.5 \pm 0.1$ & P. allius & KX901763, KX901776 \\
\hline F8 & Soybean & Foster, ND & $10 / 04 / 2015$ & 20 & + & $22.0 \pm 0.2$ & P. allius & $\ldots$, KX901777 \\
\hline $\mathrm{F} 9 *$ & Soybean & Griggs, ND & $10 / 04 / 2015$ & 20 & + & $22.7 \pm 0.0$ & P. allius & KX901764, KX901778 \\
\hline F10 & Potato & Sherburne, MN & $09 / 18 / 2015$ & 30 & + & $20.6 \pm 0.2$ & P. allius & KX901765, KX901779 \\
\hline F11 & Potato & Sherburne, MN & $09 / 18 / 2015$ & 30 & + & $21.8 \pm 0.0$ & P. allius & KX901766, KX901780 \\
\hline F12 & Potato & Sherburne, MN & $09 / 18 / 2015$ & 30 & + & $24.1 \pm 0.0$ & P. allius & KX901767, KX901781 \\
\hline F13 & Potato & Sargent, ND & $04 / 22 / 2015$ & 32 & + & $23.7 \pm 0.1$ & P. allius & KX901768, KX901782 \\
\hline F14 & Potato & Sargent, ND & $10 / 04 / 2015$ & 10 & + & $24.5 \pm 0.2$ & P. allius & KX901769, KX901783 \\
\hline F15 & Potato & Sargent, ND & $10 / 04 / 2015$ & 60 & + & $21.8 \pm 0.1$ & P. allius & KX901770, KX901784 \\
\hline F16 & Potato & Sargent, ND & $10 / 01 / 2015$ & 90 & + & $21.5 \pm 0.1$ & $\ldots$ & $\ldots$ \\
\hline F17 & Potato & Sargent, ND & $10 / 01 / 2015$ & 50 & + & $23.0 \pm 0.1$ & $\ldots$ & $\ldots$ \\
\hline F18 & Potato & Sargent, ND & $10 / 01 / 2015$ & 50 & + & $20.8 \pm 0.1$ & $\ldots$ & $\ldots$ \\
\hline NTC & $\ldots$ & $\ldots$ & $\ldots$ & $\ldots$ & - & N/A & $\ldots$ & $\ldots$ \\
\hline
\end{tabular}

${ }^{\text {a }}$ SRN from fields F6 (*) and F9 (*) were identified as Paratrichodorus allius according to morphometric characteristics. Morphological measurements of adult females in sample F6 $(n=5)$ included body length (range $=745.1$ to $865.5 \mu \mathrm{m}$, mean $=811.0 \mu \mathrm{m})$, onchiostyle length $(47.2$ to $51.5 \mu \mathrm{m}, 49.4 \mu \mathrm{m})$, body width (42.7 to $50.6 \mu \mathrm{m}, 47.1 \mu \mathrm{m})$, length from anterior end to basal bulb (130.2 to $202.2 \mu \mathrm{m}, 161.8 \mu \mathrm{m})$, a (15.8 to $18.0 \mu \mathrm{m}, 17.2 \mu \mathrm{m}), \mathrm{b}(4.3$ to $6.0 \mu \mathrm{m}, 5.1 \mu \mathrm{m})$, and $\mathrm{V}(51.5$ to $57.1 \%, 54.0 \%)$. Morphological measurements of adult females in sample F9 $(n=3)$ included body length $($ range $=771.0$ to $809.2 \mu \mathrm{m}$, mean $=786.6$ $\mu \mathrm{m}$ ), onchiostyle length ( 45.6 to $56.1 \mu \mathrm{m}, 50.2 \mu \mathrm{m}$ ), body width ( 37.0 to $39.1 \mu \mathrm{m}, 37.9 \mu \mathrm{m})$, length from anterior end to basal bulb (128.8 to $146.9 \mu \mathrm{m}, 135.5$ $\mu \mathrm{m}), \mathrm{a}(20.5$ to $21.1 \mu \mathrm{m}, 20.7 \mu \mathrm{m}), \mathrm{b}(5.3$ to $6.3 \mu \mathrm{m}, 5.8 \mu \mathrm{m})$, and $\mathrm{V}(50.8$ to $55.5 \%, 53.3 \%)$. The anus and caudal pores are subterminal. $\mathrm{NTC}=$ the nontemplate control, which used double-distilled $\mathrm{H}_{2} \mathrm{O}$ instead of DNA in a PCR

${ }^{\mathrm{b}}$ SRN density was calculated based on the number of SRN per milliliter of nematode suspension extracted from $200 \mathrm{~g}$ of field soil.

${ }^{\mathrm{c}}$ Species-specific conventional PCR assays for $P$. allius identification were performed using the primers designed in this study; + or - indicate the target-specific amplicons present or absent, respectively.

$\mathrm{d}$ The real-time PCR assay was performed using the primer set developed in this study for $P$. allius identification. N/A indicates no amplification was detected and $\mathrm{Cq}=$ quantification cycle value. Data are presented as mean \pm standard deviation of three biological replicates.

${ }^{e}$ Species identity by sequencing. Species were identified based on the Blastn alignment of sequences from the D2-D3 region of 28S ribosomal DNA (rDNA) or internal transcribed spacer (ITS) 1 rDNA against the database nucleotide collection (nr/nt), as described by Yan et al. (2016a,b); ... indicates that information was not available.

${ }^{\mathrm{f}}$ Accession numbers KX901757 to KX901770 are sequences of D2-D3 segments of 28S ribosomal RNA and accessions KX901771 to KX901784 are sequences of ITS1 rDNA. 
incubated at $60^{\circ} \mathrm{C}$ for $30 \mathrm{~min}$. Following centrifugation at $12,000 \mathrm{rpm}$ for $10 \mathrm{~min}$ at $4^{\circ} \mathrm{C}$, the supernatant was pipetted into a new $2.0-\mathrm{ml}$ microcentrifuge tube. An equal volume of phenol-chloroform-isoamyl alcohol (25:24:1) buffer was added and gently mixed. After another centrifugation at $12,000 \mathrm{rpm}$ for $10 \mathrm{~min}$ at $4^{\circ} \mathrm{C}$, the supernatant was transferred to a new $1.5-\mathrm{ml}$ microcentrifuge tube and $1 / 10$ volume of $3 \mathrm{M}$ sodium acetate ( $\mathrm{pH}$ 5.2) and 2 volumes of $95 \%$ chilled ethanol were added to precipitate DNA. After storage at $-20^{\circ} \mathrm{C}$ for at least $20 \mathrm{~min}$, DNA was pelleted by centrifugation at $12,000 \mathrm{rpm}$ for $10 \mathrm{~min}$ at $4^{\circ} \mathrm{C}$ and the resulting pellet was washed twice with cold $70 \%$ ethanol, dried, and resuspended in $100 \mu \mathrm{l}$ of PCR water. To remove humic substances from crude nematode suspensions, a further purification using polyvinyl polypyrrolidone (PVPP) columns was accomplished prior to PCR, as described by Yan et al. (2008). Finally, the $100 \mu \mathrm{l}$ of DNA extract was eluted in a PVPP column and the purified DNA was kept at $-20^{\circ} \mathrm{C}$ until use.

Another method was used to extract DNA from nematode communities (Table 2, communities 8 to 13) by a PowerSoil DNA Isolation Kit (MoBio Laboratories, Inc., Carlsbad, CA), with a few modifications. First, nematodes were collected from suspensions by centrifuging at $13,000 \mathrm{rpm}$ for $10 \mathrm{~min}$. After removing the supernatants, nematodes were resuspended into the solutions in PowerBead Tubes and then the DNA extraction continued according to the manufacturer's recommendations. The final $100 \mu \mathrm{l}$ of DNA extract was eluted from Spin Filter using double-distilled $(\mathrm{dd}) \mathrm{H}_{2} \mathrm{O}$ and was kept at $-20^{\circ} \mathrm{C}$ until use.

Species-specific primer design and in silico analysis. A multiple sequence alignment of ITS1 rDNA of six Paratrichodorus spp. obtained from GenBank was generated by the MegAlign module of the DNASTAR Lasergene software package (Madison, WI). The nematodes with corresponding GenBank accession numbers were $P$. pachydermus (JN123376.1), P. macrostylus (AY430187.1), P. minor (KJ934126.1), P. teres (AM087125.1), P. porosus (GU645907.1), and $P$. allius (KU094059.1, KJ934124.1, KT892735.1, and AM087124.1). Two pairs of primers were designed from KU094059.1, which is an isolate of $P$. allius found in a potato field in North Dakota (Yan et al. 2016b), using the PrimerSelect module of DNASTAR software. The primers were located in the conserved region among our collected $P$. allius populations. The specificity of primer pairs was initially

Table 2. Detection of Paratrichodorus allius from DNA extracts of nematode communities by conventional and real-time polymerase chain reaction (PCR)

\begin{tabular}{lllcc}
\hline Community $^{\mathbf{a}}$ & $\begin{array}{c}\text { Field } \\
\text { ID }\end{array}$ & \multicolumn{1}{c}{ Origin } & $\begin{array}{c}\text { Conventional } \\
\text { PCR }^{\mathbf{b}}\end{array}$ & Cq value $^{\mathbf{c}}$ \\
\hline 1 & C\#1a & Sargent, ND & + & $\ldots$ \\
2 & C\#1c & Sargent, ND & + & $\ldots$ \\
3 & C\#1d & Sargent, ND & + & $\ldots$ \\
4 & C\#5 & Sargent, ND & + & $\ldots$ \\
5 & C\#8 & Sargent, ND & + & $\ldots$ \\
6 & C\#14 & Sargent, ND & + & $\ldots$ \\
7 & W\#13 & McKenzie, ND & + & $\ldots$ \\
8 & F3 & Clay, MN & + & $21.32 \pm 0.07$ \\
9 & F6 & Richland, ND & + & $24.37 \pm 0.02$ \\
10 & F9 & Griggs, ND & + & $28.26 \pm 0.11$ \\
11 & F15 & Sargent, ND & + & $23.00 \pm 0.09$ \\
12 & N1 & Sargent, ND & - & N/A \\
13 & N2 & Sargent, ND & - & N/A \\
\hline
\end{tabular}

a Communities 1 to 6 were extracted from soils collected from potato fields in Sargent County, ND that were infested with P. allius; community 7 was extracted from a soil collected from a wheat field in McKenzie County, ND that was infested with $P$. allius; communities 8 to 11 were extracted from corresponding fields listed in Table 1; and communities 12 and 13 were extracted from soils collected from potato fields in Sargent County, ND that did not contain stubby root nematodes.

b Symbols + or - indicate the presence or absence, respectively, of target PCR products.

${ }^{c}$ Quantification cycle value $(\mathrm{Cq})$ was presented as mean \pm standard deviation from three biological replicates; ... indicates data not available and N/A = no amplification observed. evaluated using the Blastn alignment program at the National Center for Biotechnology Information (NCBI) and results revealed no perfect match with other plant-parasitic nematode sequences in the database nucleotide collection (nr/nt) (http://www.ncbi.nlm.nih.gov/). Primers were synthesized by Eurofin MWG Operon LLC (Huntsville, AL). The performance of designed primer pairs on PCR amplification regarding the specificity and efficiency was evaluated using DNA from $P$. allius, $P$. porosus, and $T$. obtusus.

Moreover, to further predict the specificity of designed primers to ITS sequences of additional stubby root nematode species and isolates, in silico analysis was performed using ITS sequences available in GenBank (Table 4) by PrimerSelect module of DNASTAR Lasergene software. In total, 34 sequences from 14 stubby root nematode species were analyzed, including 7 Paratrichodorus spp. and 7 Trichodorus spp. They were two isolates of each of $P$. allius, $P$. porosus, $P$. pachydermus, T. similis, T. sparsus, and T. nanjingensis; one isolate of each of $P$. teres, $T$. viruliferus, and $T$. cedarus; four isolates of $P$. minor; three isolates of each of $P$. macrostylus, $T$. primitivus, and $T$. pakistanensis; and six isolates of $P$. renifer from eight countries (Table 4). The specificity of primers to the sequences was determined by primer-template duplex stability $(\Delta \mathrm{G})$, as described by Schroeder et al. (2006), Okubara et al. (2008), and Yan et al. (2008, 2012, 2013a,b).

Primer specificity testing. The specificity of primers was further investigated using DNA from confirmed species of stubby root nematodes and other nematodes consisting of 42 isolates from 29 species (Table 3). They included four species of stubby root nematodes (Paratrichodorus and Trichodorus spp.), 12 cyst nematode species (Heterodera, Cactodera, and Globodera spp.), two root-knot nematode species (Meloidogyne spp.), five root-lesion nematode species (Pratylenchus spp.), and six species of other plantparasitic nematodes (Helicotylenchus, Paratylenchus, Hoplolaimus, Xiphinema, Tylenchorhynchus, and Mesocriconema spp.) that were found coexisting with stubby root nematodes in the same fields. For the DNA samples extracted in our lab, three independent DNA extractions were conducted for each sample and used as biological replicates.

Conventional and real-time PCR assays. To check the quality of DNA extracts, universal primer set D3A/D3B or rDNA2/rDNA1.58s was used to amplify the D3 expansion region of 28S rDNA or ITS1 rDNA, respectively. The PCR amplification was conducted as described by Yan et al. (2013a) and Cherry et al. (1997). All conventional PCR were performed on a Bio-Rad T100 Thermal Cycler (Hercules, CA). The species-specific PCR comprised $1.0 \mu \mathrm{l}$ of DNA template, $0.4 \mu \mathrm{M}$ forward and reverse primers, $0.2 \mathrm{mM}$ dNTP, $1.5 \mathrm{mM} \mathrm{MgCl}_{2}, 1 \times$ Green GoTaq Flexi buffer, and $1 \mathrm{U}$ of GoTaq Flexi DNA Polymerase (Promega Corp., Madison, WI), and was amplified under the conditions of predenaturing at $94^{\circ} \mathrm{C}$ for $3 \mathrm{~min}$; followed by 35 cycles of $94^{\circ} \mathrm{C}$ for $40 \mathrm{~s}, 60^{\circ} \mathrm{C}$ for $50 \mathrm{~s}$, and $72^{\circ} \mathrm{C}$ for $1 \mathrm{~min}$; with a final extension at $72^{\circ} \mathrm{C}$ for $10 \mathrm{~min}$. To improve the amplification for DNA extracted from nematode suspensions, a PCR enhancer bovine serum albumin at a final concentration of $0.8 \mu \mathrm{g} / \mu \mathrm{l}$ was added into each PCR (Yan et al. 2008). All PCR amplifications were performed twice, independently, as technical replicates. The banding patterns of PCR products were documented by the AlphaImager Gel Documentation System (Proteinsimple Inc., Santa Clara, California) after separation in $2 \%$ agarose gel at $100 \mathrm{~V}$ for $20 \mathrm{~min}$.

To test whether primers can be used in the real-time PCR assay for $P$. allius identification, a SYBR-based real-time PCR assay was conducted. The real-time PCR amplification was performed on Bio-Rad CFX96 Touch Real-time PCR Detection System using SsoAdvanced Universal SYBR Green Supermix (Bio-Rad) with $1.0 \mu$ l of DNA template and $0.4 \mu \mathrm{M}$ primer concentration, according to the manufacturer's instructions. The cycling conditions were as follows: incubation at $95^{\circ} \mathrm{C}$ for $4 \mathrm{~min}, 35$ cycles of $95^{\circ} \mathrm{C}$ for $10 \mathrm{~s}$ and $60^{\circ} \mathrm{C}$ for $30 \mathrm{~s}$, followed by melting curve analysis using the default set to evaluate the amplification specificity. A nontemplate control, using $\mathrm{ddH}_{2} \mathrm{O}$ instead of DNA in the real-time PCR, was run for each experiment. Each DNA sample was run twice as technical replicates. The data were analyzed using Bio-Rad CFX Manager Software V3.1. The quantification cycle value $(\mathrm{Cq})$ was determined at the default 
settings. PCR product identity was confirmed by electrophoresis on a $2 \%$ agarose gel.

PCR detection sensitivity analysis. To determine the minimum template used in PCR that could be detected by conventional and real-time PCR assays, DNA was extracted from 1, 2, 5, and 10 individuals of $P$. allius from a potato field in Sargent County, ND using the Proteinase K method (Kumari and Subbotin (2012), as described above. The concentration of DNA extracts was measured by a NanoDrop-1000 spectrophotometer (Thermo Scientific, Wilmington, DE). A set of template DNA from serial dilutions of three independent DNA extracts having an equivalent DNA amount of $3 \mathrm{ng}$ to $1.92 \times 10^{-4} \mathrm{ng}$ with a dilution factor of five was used in the PCR (Fig. 1; Table 5). The sensitivity referred to the minimum quantity of DNA template that could produce visible amplicons in the conventional PCR assay or generate a Cq value lower than 34 in the real-time PCR assay. A nontemplate control containing $\mathrm{ddH}_{2} \mathrm{O}$ instead of DNA was used as negative control in the whole experiment. PCR were run three times for each DNA template as technical replicates and three DNA, extracted independently, were used as biological replicates. To test the capability of designed primers in the real-time PCR assay, the amplification efficiency (E) and coefficient of determination $\left(R^{2}\right)$ were calculated automatically by Bio-Rad CFX Manager Software V3.1, according to the Cq value generated from the serial dilutions against the corresponding $\log _{10}$ amount of template DNA.

Identification of $P$. allius isolated from field samples using PCR assays. To evaluate the performance of developed PCR assays on the diagnosis of $P$. allius nematodes isolated from field samples, PCR assays were tested using DNA extracted from single individuals

Table 3. Taxon, geographic origin, host, and polymerase chain reaction (PCR) assays of the control nematode species used in this study to test the primer specificity

\begin{tabular}{|c|c|c|c|c|c|}
\hline Code $^{\mathbf{a}}$ & Species & Origin $^{b}$ & Host $^{\mathbf{b}}$ & $\mathbf{P C R}^{\mathrm{c}}$ & $\mathbf{C q}^{\mathrm{d}}$ \\
\hline 1 & Paratrichodorus allius & North Dakota & Potato & + & $22.98 \pm 0.03$ \\
\hline 2 & P. allius & Minnesota & Sugarbeet & + & $23.31 \pm 0.24$ \\
\hline 3 & P. porosus & South Carolina & Spinach & - & N/A \\
\hline 4 & P. porosus & North Carolina & Soybean & - & N/A \\
\hline 5 & P. minor & North Carolina & Soybean & - & N/A \\
\hline 6 & Trichodorus. obtusus & South Carolina & Golfgrass & - & N/A \\
\hline 7 & T. obtusus & Florida & Golfgrass & - & N/A \\
\hline 8 & Heterodera schachtii & Oregon & Sugarbeet & - & N/A \\
\hline 9 & H. trifolii & Greece & Spanish vetchling & - & N/A \\
\hline 10 & H. zea & Egypt & Potato & - & N/A \\
\hline 11 & H. filipjevi & Oregon & Wheat & - & N/A \\
\hline 12 & H. avenae & Oregon & Wheat & - & N/A \\
\hline 13 & H. glycine & North Dakota & Potato & - & N/A \\
\hline 14 & Cactodera weissi & New York & Potato & - & N/A \\
\hline 15 & C. milleri & Colorado & Quinoa & - & N/A \\
\hline 16 & C. milleri & Minnesota & Potato & - & N/A \\
\hline 17 & Globodera ellingtonae & Oregon & Potato & - & N/A \\
\hline 18 & G. pallida & Idaho & $\ldots$ & - & N/A \\
\hline 19 & G. rostochiensis & New York & $\ldots$ & - & N/A \\
\hline 20 & G. rostochiensis & Canada & Potato & - & N/A \\
\hline 21 & G. tabacum solanacearum & Virginia & $\ldots$ & - & N/A \\
\hline 22 & G. tabacum tabacum & Connecticut & $\ldots$ & - & N/A \\
\hline 23 & Meloidogyne chitwoodi & Washington & Potato & - & N/A \\
\hline 24 & M. nassi & California & Poa/bent & - & N/A \\
\hline 25 & Pratylenchus penetrans & $\ldots$ & $\ldots$ & - & N/A \\
\hline 26 & P. penetrans & Maryland & $\ldots$ & - & N/A \\
\hline 27 & P. neglectus & Canada & $\ldots$ & - & N/A \\
\hline 28 & P. neglectus & $\ldots$ & $\ldots$ & - & N/A \\
\hline 29 & P. neglectus & North Dakota & Wheat & - & N/A \\
\hline 30 & P. neglectus & Oregon & Wheat & - & N/A \\
\hline 31 & P. scribneri & Florida & Tomato & - & N/A \\
\hline 32 & P. scribneri & North Dakota & Potato & - & N/A \\
\hline 33 & P. thornei & $\ldots$ & $\ldots$ & - & N/A \\
\hline 34 & P. thornei & Oregon & Wheat & - & N/A \\
\hline 35 & P. zeae & $\ldots$ & $\ldots$ & - & N/A \\
\hline 36 & P. zeae & Singapore & Spider lily & - & N/A \\
\hline 37 & Helicotylenchus sp. & Minnesota & Sugarbeet & - & N/A \\
\hline 38 & Paratylenchus sp. & North Dakota & Field pea & - & N/A \\
\hline 39 & Hoplolaimus sp. & North Dakota & Soybean & - & N/A \\
\hline 40 & Xiphinema sp. & North Dakota & Soybean & - & N/A \\
\hline 41 & Tylenchorhynchus sp. & North Dakota & Soybean & - & N/A \\
\hline 42 & Mesocriconema sp. & North Dakota & Potato & - & N/A \\
\hline
\end{tabular}

${ }^{a}$ DNA samples $1,2,13,29,32$, and 37 to 42 were collected by our lab; 11, 12, 30, and 34 were acquired from Oregon State University; and 8 to 10,14 to 28,31 , 33, 35, and 36 were acquired from United States Department of Agriculture-Agricultural Research Service Nematology Laboratory. Soil of samples 3 and 6 was acquired from Clemson University and soil of sample 7 was acquired from the University of Florida. Nematode suspensions of samples 4 and 5 were acquired from North Carolina Department of Agriculture \& Consumer Services; samples 37 to 42 were plant-parasitic nematodes collected by our lab that were commonly present in North Dakota or Minnesota and were identified to genus by morphological features; however, the species were unknown.

${ }^{\mathrm{b}}$ Symbol ... indicates no information available.

${ }^{\mathrm{c}}$ Symbols + or - indicate the presence or absence, respectively, of target amplicons using the conventional PCR assay with designed specific primers $\mathrm{PaF} 11 / \mathrm{PaR} 12$

${ }^{\mathrm{d}}$ Quantification cycle value $(\mathrm{Cq})$ was presented as mean \pm standard deviation of three replicates in the real-time PCR assay with designed specific primers $\mathrm{PaF} 11 / \mathrm{PaR} 12$. N/A indicates that no amplification was detected by real-time PCR. 
of stubby root nematodes from field samples in North Dakota and Minnesota (Table 1). The field samples were distributed in two counties in Minnesota and five counties in North Dakota on five crops. Both conventional and real-time PCR assays were performed as described above. The banding pattern of a conventional PCR assay and $\mathrm{Cq}$ value of a real-time PCR assay were recorded. The amplification and presence of target amplicons were analyzed to investigate the existence of $P$. allius. Furthermore, the capabilities of developed conventional and real-time PCR assays on detection of $P$. allius from complex nematode communities possessing various other plantparasitic nematodes (such as Pratylenchus and Helicotylenchus spp.) and nematodes that are not plant parasites were also determined (Table 2). Meanwhile, two negative controls using DNA extracted from nematode communities without target nematodes were tested.

Species identity confirmation by sequencing. To assign the species identity of collected stubby root nematodes, sequence information of two genomic regions were obtained by either cloning and plasmid sequencing or direct sequencing of purified PCR products. The D2-D3 expansion region of 28S rDNA was amplified by primers D2A (5'-ACAAGTACCGTGAGGGAAAGTTG-3') and D3B (5'-T CGGAAGGAACCAGCTACTA-3') (Subbotin et al. 2008). The ITS1 region of rDNA was amplified by primers BL18 (5'-GTTTCCGT AGGTGAACCTGC-3') and 5818 (5'-ATATGCTTAAGTTCAGCG GGT-3') (Boutsika et al. 2004a). PCR amplifications were performed from DNA extracted from single nematodes. Three biological replicates for each nematode population were used. For direct sequencing, three
PCR products from three DNA extractions of each sample were first purified by the PCR Extract Mini Kit (5 PRIME Inc., Gaithersburg, MD) and then submitted for sequencing. For cloning and plasmid sequencing, each purified PCR product was ligated into the pGEM-T easy

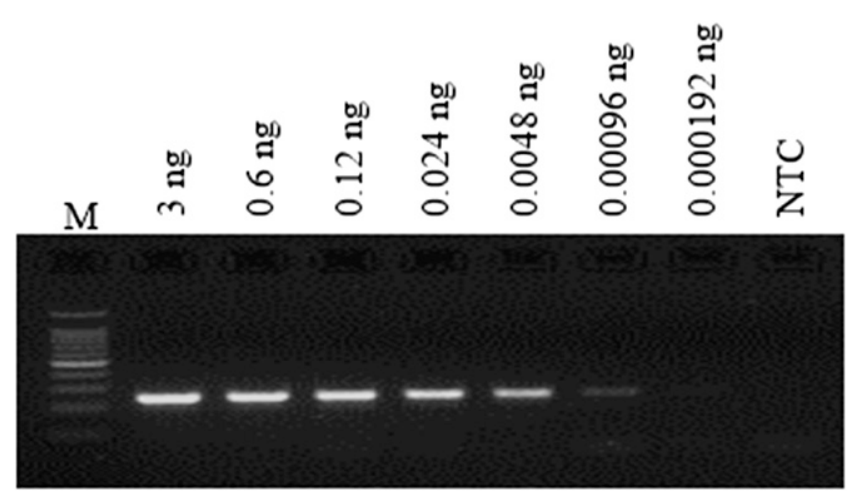

Fig. 1. Amplification sensitivity analysis in conventional polymerase chain reaction (PCR). DNA was extracted from single nematodes collected from the potato field in North Dakota where Paratrichodorus allius was originally found. A set of dilutions was used as template in the PCR containing 3 to $1.92 \times 10^{-4} \mathrm{ng}$ of DNA. Lane $\mathrm{M}=100-\mathrm{bp}$ DNA ladder (Promega Corp.) and NTC = nontemplate control using double-distilled $\mathrm{H}_{2} \mathrm{O}$ instead of DNA in the PCR.

Table 4. Stubby root nematode species and GenBank accession number of internal transcribed spacer sequences used for analysis of primer-template duplex stability $(\Delta \mathrm{G})$ for predicting the specificity of primers $(\mathrm{PaF} 11 / \mathrm{PaR} 12)$ for Paratrichodorus allius

\begin{tabular}{|c|c|c|c|c|c|}
\hline \multirow[b]{2}{*}{ Species } & \multirow[b]{2}{*}{ GenBank } & \multirow[b]{2}{*}{ Isolate or clone $\mathrm{e}^{\mathrm{b}}$} & \multirow[b]{2}{*}{ Origin } & \multicolumn{2}{|c|}{$\Delta \mathrm{G}(\mathrm{kcal} / \mathrm{mol})^{\mathrm{a}}$} \\
\hline & & & & PaF11 & PaR12 \\
\hline Paratrichodorus allius & KU094059.1 & ND000007 & North Dakota & -41.1 & -37.8 \\
\hline P. allius & KJ934124.1 & T52 1130383 & North Carolina & -41.1 & -37.8 \\
\hline P. teres & AM087125.1 & Columbia basin & Washington & ins & ins \\
\hline P. porosus & GU645907.1 & ZJ-19 & China & ins & -35.8 \\
\hline P. porosus & JQ217090.1 & $\mathrm{Ja} /$ Clone2 & Japan & ins & -35.8 \\
\hline P. minor & GU645814.1 & HN-41 & China & ins & ins \\
\hline P. minor & GU645903.1 & $\mathrm{HN}-44$ & China & ins & ins \\
\hline P. minor & KJ934125.1 & T43 1130365 & South Carolina & ins & ins \\
\hline P. minor & KJ934126.1 & T20 116013 & Puerto Rico & ins & ins \\
\hline P. pachydermus & AJ439513.1 & N/A & Woodhill, United Kingdom & ins & ins \\
\hline P. pachydermus & JN123376.1 & PP1 & Jesen, Czech Republic & ins & ins \\
\hline P. macrostylus & AY430187.1 & N/A & Belgium & ins & ins \\
\hline P. macrostylus & AJ439508.1 & N/A & Kralovsky Chlmec, Slovakia & ins & ins \\
\hline P. macrostylus & AJ439510.1 & N/A & Kralovsky Chlmec, Slovakia & ins & ins \\
\hline P. renifer & EU827611.1 & N/A & Belgium & ins & ins \\
\hline$P$. renifer & GQ489245.1 & N/A & British Columbia, Canada & ins & ins \\
\hline P. renifer & GQ489246.1 & N/A & Washington & ins & ins \\
\hline P. renifer & GU645914.1 & ZJ-90 & China & ins & ins \\
\hline P. renifer & GU645915.1 & ZJ-106R & China & ins & ins \\
\hline P. renifer & JQ217080.1 & $\mathrm{Ch} /$ Clone2 & China & ins & ins \\
\hline Trichodorus similis & JN123377.1 & TS3 & Czech Republic, Ceveny Vrch & ins & ins \\
\hline T. similis & AJ439523.1 & N/A & Kinshaldy, United Kingdom & ins & ins \\
\hline T. primitivus & AJ439518.1 & N/A & Tentsmuir, United Kingdom & ins & ins \\
\hline T. primitivus & AJ439520.1 & N/A & Tentsmuir, United Kingdom & ins & ins \\
\hline T. primitivus & JN123385.1 & $\mathrm{TP} 2$ & Ratiskovice, Czech Republic & ins & ins \\
\hline T. viruliferus & $\mathrm{KC} 160453.1$ & 6160 & Italy & -20.6 & ins \\
\hline T. sparsus & JN123378.1 & TS4 & Obrubce, Czech Republic & ins & ins \\
\hline T. sparsus & JN123379.1 & TS5 & Borek, Czech Republic & ins & ins \\
\hline T. cedarus & HM106500.1 & $\mathrm{ZJ}-8$ & China & ins & ins \\
\hline T. nanjingensis & GU645916.1 & $\mathrm{ZJ}-5$ & China & ins & ins \\
\hline T. nanjingensis & GU645919.1 & BJ-88 & China & ins & ins \\
\hline T. pakistanensis & GU645828.1 & CQ-10 & China & ins & -19.1 \\
\hline T. pakistanensis & GU645830.1 & FJ-111 & China & ins & -19.1 \\
\hline T. pakistanensis & GU645920.1 & YN-76 & China & ins & -19.1 \\
\hline
\end{tabular}

${ }^{\text {a }}$ Value $<-31 \mathrm{kcal} / \mathrm{mol}$ indicates a stable primer-template formation for a PCR amplification; ins or value $>-31 \mathrm{kcal} / \mathrm{mol}=$ insignificant or poor primer-template duplex stability for a PCR amplification.

${ }^{b}$ Name of isolates or clones obtained from GenBank; N/A = the information is not available in GenBank. 
vector (Promega Corp.), as described by Tanha Maafi et al. (2003). Three plasmid DNA extracted from positive colonies for each population were submitted for sequencing. The sequencing information was provided by Genscript (Piscataway, NJ). A Blastn alignment was performed in NCBI (https://blast.ncbi.nlm.nih.gov/Blast.cgi) using the database nucleotide collection (nr/nt) to identify the species.

\section{Results}

Primer specificity. One of the primer pairs, $\mathrm{PaF} 11$ (forward, $5^{\prime}$ AAGCTTGCTGGTAGTTTGTTGG-3') and PaR12 (reverse, 5'AAGTAGTTAAAAGGGGAGTCG-3'), which had a better amplification performance after testing with DNA of P. allius, P. porosus, and $T$. obtusus, was selected in this study. In silico analysis was performed to analyze the primer specificity before the experiments. Specific amplification was reflected in $\Delta \mathrm{G}$ values of $-31 \mathrm{kcal} / \mathrm{mol}$ or less for the forward and reverse primers (Yan et al. 2013a). The forward primer PaF11 (22 bp) was predicted to form a stable hybrid with the ITS sequence of two P. allius isolates from North Dakota and North Carolina in the United States $(\Delta \mathrm{G}=-41.1)$, a poor hybrid with ITS sequence of one $T$. viruliferus isolate from Italy $(\Delta \mathrm{G}=-20.6)$, and no hybrid with ITS sequences of other stubby root nematode species $(\Delta \mathrm{G}=$ ins), including six Paratrichodorus spp. (P. teres, P. porosus, P. minor, $P$. pachydermus. $P$. macrostylus, and $P$. renifer) and six Trichodorus spp. (T. similis. T. primitivus, T. sparsus. T. cedarus, T. nanjingensis, and $T$. pakistanensis) (Table 4). The reverse primer PaR12 (21 bp) was predicted to form a stable hybrid with the ITS sequence of two isolates of $P$. allius $(\Delta \mathrm{G}=-37.8)$ and two isolates of $P$. porosus $(\Delta \mathrm{G}=$ -35.8), a poor hybrid with three isolates of $T$. pakistanensis $(\Delta \mathrm{G}=$ -19.1 ), and no hybrid with ITS sequences of the rest of the stubby root nematode species (Table 4). Because the amplification from a single primer (unidirectional PCR) normally failed to generate enough products to be detected by PCR (Okubara et al. 2008), we predicted that the designed primer set PaF11/PaR12 could be expected to specifically amplify the DNA of $2 P$. allius isolates from the United States but not the DNA of the other 13 stubby root nematode species listed in Table 4 based on $\Delta \mathrm{G}$ values.

Table 5. Quantification cycle $(\mathrm{Cq})$ numbers from serial dilutions of DNA extracts of single nematodes of Paratrichodorus allius

\begin{tabular}{llc}
\hline Sample $^{\mathbf{a}}$ & DNA (ng) & Cq value $^{\mathbf{b}}$ \\
\hline 1 & 3 & $18.54 \pm 0.11$ \\
2 & 0.6 & $20.91 \pm 0.54$ \\
3 & 0.12 & $23.20 \pm 0.08$ \\
4 & 0.024 & $25.35 \pm 0.42$ \\
5 & 0.0048 & $27.80 \pm 0.26$ \\
6 & 0.00096 & $30.42 \pm 0.46$ \\
7 & 0.000192 & $32.17 \pm 1.17$ \\
NTC & 0 & N/A \\
Efficiency $(E)$ & $\ldots$ & $100.2 \%$ \\
Coefficient $\left(R^{2}\right)$ & $\ldots$ & 0.998 \\
\hline
\end{tabular}

${ }^{\text {a }}$ NTC $=$ nontemplate control using double-distilled $\mathrm{H}_{2} \mathrm{O}$ instead of DNA.

${ }^{b}$ The $\mathrm{Cq}$ value was presented as mean \pm standard deviation from three replicates. $\mathrm{N} / \mathrm{A}=$ no amplification detected by real-time polymerase chain reaction.
The experimental PCR supported the prediction of primer specificity by in silico analysis. As expected, a specific 246-bp fragment was amplified from the DNA of $P$. allius (Table 3, codes 1 and 2) using conventional PCR with the designed specific primer set PaF11/ PaR12. Using nontarget nematode control samples (Table 3, codes 3 to 42), the specificity of this primer set in PCR assays was analyzed. For example, the conventional PCR successfully amplified DNA from tested species using a universal nematode detection primer set D3A/D3B, indicating the presence of template DNA (Fig. 2). Using the specific primer set $\mathrm{PaF} 11 / \mathrm{PaR} 12$, the conventional PCR only amplified DNA from two isolates of $P$. allius in North Dakota and Minnesota, whereas no amplification was observed from 3 other stubby root nematode species ( $P$. porosus, $P$. minor, and $T$. obtusus) and 25 nonstubby root nematodes species consisting of 6 Heterodera spp., 2 Cactodera spp., 4 Globodera spp., 2 Meloidogyne spp., 5 Pratylenchus spp., 1 Helicotylenchus sp., 1 Paratylenchus sp., 1 Hoplolaimus sp., 1 Xiphinema sp., 1 Tylenchorhynchus sp., and 1 Mesocriconema sp. (Table 3; Fig. 2). Additionally, nontemplate controls that contained water instead of DNA yielded no amplification. Similarly, using the same set of DNA as template in the real-time PCR assay, the amplification was only detected in two DNA of $P$. allius, with Cq values at $22.98 \pm 0.03$ and $23.31 \pm 0.24$, respectively (Table 3 ), and no amplification was detected in nonstubby root nematode species and nontemplate controls. The melting curve analysis revealed single amplicons with a melting peak at $87.0^{\circ} \mathrm{C}$ (Fig. 3), specific for the two isolates of $P$. allius.

PCR assay sensitivity. The target PCR products were amplified from DNA extracted from 1, 2, 5, and 10 individuals of $P$. allius by conventional PCR assay. In addition, the real-time PCR using DNA extracted from 1, 2, 5, and 10 individuals generated Cq values $23.00 \pm 0.08,21.79 \pm 0.41,19.43 \pm 0.35$, and $18.17 \pm 0.22$, respectively. To evaluate the minimum amount of DNA template that could be detected by developed PCR assays, PCR was carried out using a serial dilution of template derived from DNA extracted from single individuals of $P$. allius originally collected from a potato field in Sargent County, ND that was previously demonstrated to be infested by this nematode species (Yan et al. 2016b). As expected, the accumulated PCR products were gradually reduced in the conventional PCR assay (Fig. 1) and the Cq values were continuously increased in the real-time PCR assay (Table 5), in agreement with the decreasing quantity of DNA template. As little as $9.6 \times 10^{-4} \mathrm{ng}$ of DNA template produced visible amplification of the target PCR fragment in the conventional PCR assay. With a higher sensitivity, the real-time PCR assay could detect the target DNA in an amount of as small as $1.92 \times 10^{-4} \mathrm{ng}$ with $\mathrm{Cq}$ at $32.17 \pm 1.17$. Based on the data obtained from serial dilutions (Table 5), the $R^{2}$ between Cq value and the $\log _{10}$ value of the template DNA quantity was 0.998 . The $\mathrm{E}$ of primer set PaF11/PaR12, which was calculated by the equation $\mathrm{E}=10^{(-1 / \text { slope })}-1$, was $100.2 \%$. These two indexes indicated that the primer set PaF11/ PaR12 was suitable for use in the real-time PCR assay.

Identifying $\boldsymbol{P}$. allius isolated from infested fields. The performance of developed PCR assays on identifying P. allius from nematodes isolated from infested field samples was investigated using DNA extracted from single stubby root nematodes coming from a

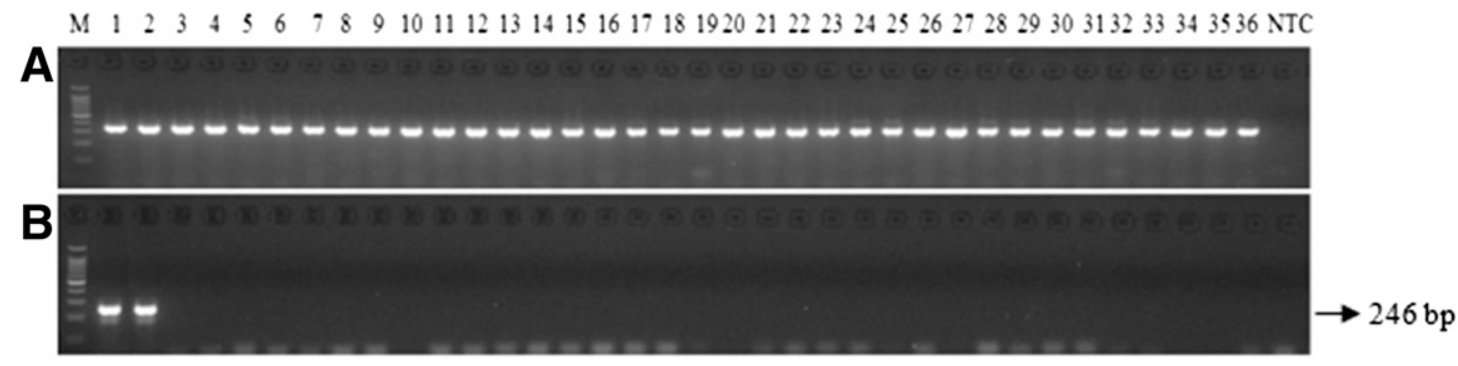

Fig. 2. Partial conventional polymerase chain reaction (PCR) results for primer specificity analysis using confirmed nematode control species. $A$, Amplification using $D 3 A$ and $D 3 B$ primers served as an internal control to determine the presence of template DNA. B, Amplification using Paratrichodorus allius species-specific primers (246 bp). Lane $\mathrm{M}=100-\mathrm{bp}$ DNA ladder (Promega Corp.), lanes 1 to 36 indicate the corresponding DNA listed in Table 3 , and NTC = nontemplate control using double-distilled $\mathrm{H}_{2} \mathrm{O}$ instead of DNA in the PCR 
range of populations distributed in 18 fields on five crops in North Dakota and Minnesota. The target-specific amplicons were observed in all the DNA samples using the conventional PCR with primer set $\mathrm{PaF} 11 / \mathrm{PaR} 12$ and no amplicon was observed in the nontemplate control (Table 1). Likewise, real-time PCR positively produced $\mathrm{Cq}$ values in all the samples ranging from $18.9 \pm 0.0$ to $27.5 \pm 0.1$, except the negative control using $\mathrm{ddH}_{2} \mathrm{O}$ instead of DNA in the PCR. Thus, the stubby root nematodes were identified as $P$. allius by our PCR assays.

Eleven nematode communities with stubby root nematodes and two nematode communities without target nematodes were used to test the ability of our developed PCR assays on $P$. allius detection from a set of nontarget nematodes. Conventional PCR using the universal primer set rDNA2/rDNA1.58s amplified DNA extracts of all 13 nematode communities (Fig. 4A), as well as positive control of $P$. allius DNA, indicating the presence of DNA templates. Positive amplifications (246 bp) were observed from DNA of 11 nematode communities harboring stubby root nematodes and the positive control using DNA extracted from a single $P$. allius individual. No amplification was detected using the negative controls harboring no stubby root nematodes and the no-template control using $\mathrm{ddH}_{2} \mathrm{O}$ instead of DNA in the PCR (Fig. 4B; Table 2). The real-time PCR assay failed to generate $\mathrm{Cq}$ values using DNA extracted from communities 1 to 7 by the PCI method and only generated Cq values using DNA extracted by the commercial kit (communities 8 to 11), ranging from $21.32 \pm 0.07$ to $28.26 \pm 0.11$ (Table 2 ). No amplification was observed using DNA templates extracted from nematode communities without target nematodes (communities 12 and 13).

Species confirmation by sequencing. To confirm the accuracy of species identity, 15 stubby root nematode populations in Table 1 were sequenced in the D2-D3 expansion region of $28 \mathrm{~S}$ rDNA or ITS1 rDNA. 28S D2-D3 and ITS1 rDNA were directly sequenced using PCR products from samples F2 to F5, F7, and F9 to F13, and were cloned and sequenced using plasmids from samples F1, F14, and F15. In addition, the 28S D2-D3 of sample F6 and ITS1 rDNA of sample F8 were directly sequenced using PCR products. Sequences were deposited into the GenBank database and the corresponding accession numbers are shown in Table 1. Due to different sequencing quality and reading length obtained, sequences of the D2-D3 region were 648 to $799 \mathrm{bp}$. The nucleotide sequence analysis showed that all nematodes had almost identical sequences of the D2D3 region (identity 99.0 to $100 \%$ ) among each other, which were $100 \%$ identical with P. allius found in either North Dakota (GenBank accession number KU094057.1) or Minnesota (KT892732.1). For ITS1 rDNA, the reading length of obtained sequences was 760 to $832 \mathrm{bp}$, according to the sequencing results. Even though the ITS1 rDNA of stubby root nematodes was more diverse (identity 97.4 to

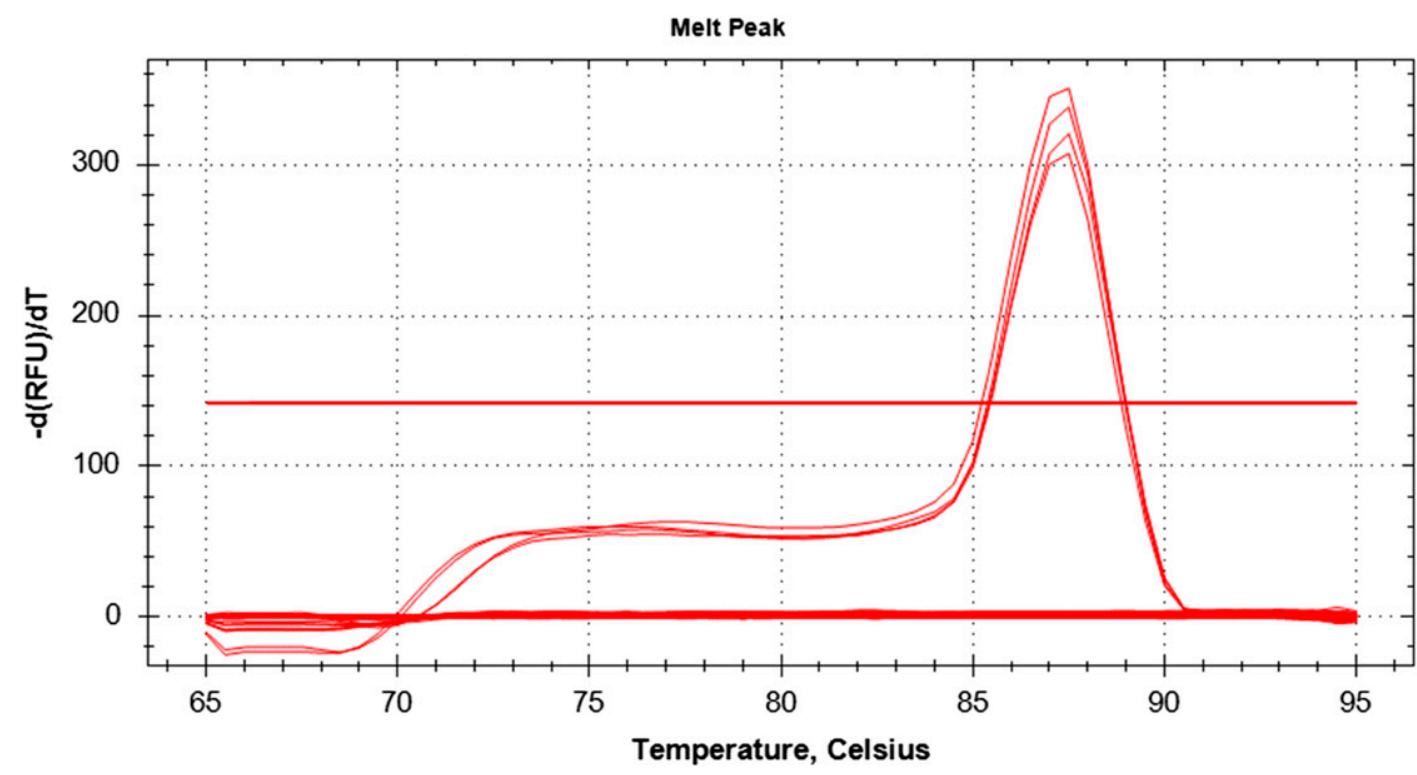

Fig. 3. Melting curve of Paratrichodorus allius-specific amplicons with melting temperature at $87.0^{\circ} \mathrm{C}$.
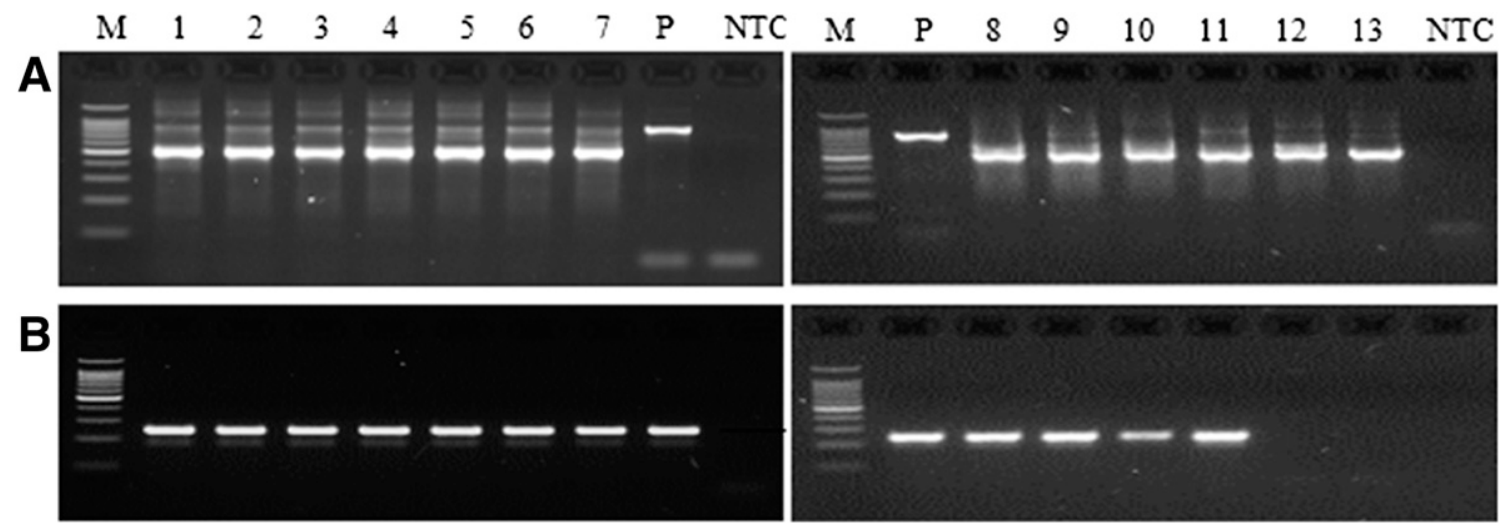

Fig. 4. Species-specific conventional polymerase chain reaction detection of Paratrichodorus allius from nematode communities. A, Amplification using rDNA2 and rDNA1.58s primers served as an internal control to determine the presence of template DNA. B, Amplification using $P$. allius-specific primers (246 bp). Lane M = 100-bp DNA ladder (Promega Corp.), $\mathrm{P}=$ positive control using DNA of $P$. allius, NTC = nontemplate control using double-distilled $\mathrm{H}_{2} \mathrm{O}$ instead of DNA, and lanes 1 to 13 indicates the DNA extracted from nematode communities listed in Table 2. 
$100 \%$ among each other) than the 28S D2-D3 region, the identity to $P$. allius ITS1 reported in either North Dakota (GenBank accession number KU094059.1) or Minnesota (KT892735.1) were 99 to $100 \%$. The Blastn alignment results using the database nucleotide collection (nr/nt) identified all of the tested stubby root nematodes as P. allius, revealing the reliability of PCR assays on $P$. allius identification from either an individual nematode or a nematode community. Moreover, stubby root nematodes isolated from fields F6 and F9 were confirmed as $P$. allius according to morphometric measurements (Table 1).

\section{Discussion}

The primer set $\mathrm{PaF} 11 / \mathrm{PaR} 12$ designed in this study was effective for specific amplification of DNA from the stubby root nematode $P$. allius in conventional PCR as well as SYBR-based real-time PCR. The specificity of the primer set was demonstrated by the amplification observed only from DNA of $P$. allius but not from nontarget nematode species and the single melting peak observed in the realtime PCR assay. The successful utilization of the primer set PaF11/ PaR12 for molecular detection and identification of $P$. allius was confirmed by the positive amplification of DNA extracted from $P$. allius populations from various fields on several crops, as well as of DNA extracted from nematode communities harboring $P$. allius, other plant-parasitic nematodes, and nematodes that are not plant parasites. This study is the first report of $P$. allius detection and identification using real-time PCR, and will provide useful information for quantification of this nematode directly from nematode communities or soil samples.

The species-specific primers in this study were designed from ITS rDNA that was considered as a variable region of rDNA and were homologous to $P$. allius isolates in the GenBank according to Blastn alignment results using the database nucleotide collection $(\mathrm{nr} / \mathrm{nt})$. Many studies have been done to identify nematode species using species-specific primers designed from rDNA, including 18S rDNA and $28 \mathrm{~S}$ rDNA, but ITS rDNA has more diversity at the species level and is ideal for use in molecular diagnostics of plant-parasitic nematodes (Boutsika et al. 2004b; Riga et al. 2007). Boutsika et al. (2004a) characterized the $18 \mathrm{~S}, 5.8 \mathrm{~S}$, and ITS rDNA sequences from the stubby root nematodes $P$. macrostylus, $P$. pachydermus, $T$. primitivus, and $T$. similis and found that the $18 \mathrm{~S}$ and $5.8 \mathrm{~S}$ genes were highly conserved while the ITS rDNA were highly variable. Using that knowledge, Boutsika et al. (2004b) successfully differentiated those four stubby root nematode species by PCR with specific primers designed from ITS rDNA. To identify $P$. allius, Riga et al. (2007) previously reported a PCR method using a pair of species-specific primers (BL18/PAR2). However, the primer specificity was only tested with nontarget, unidentified plant-parasitic nematode species found in local areas, including Paratylenchus spp. (pin nematode), Tylenchorhynchus spp. (stunt nematode), Criconemella spp. (ring nematode), Meloidogyne spp. (root knot nematode), and Ditylenchus spp. (stem nematode). According to our preexperiments (data not shown), primer pair BL18/PAR2 cross-reacted with DNA from pin nematodes and spiral nematodes that coexisted with stubby root nematodes in North Dakota, challenging the application of these two primers used for the detection and identification of $P$. allius in our area.

In this study, the designed $P$. allius primers are located in conserved region of ITS1 rDNA. Because only three other stubby root nematode species were obtained in this study upon request, in silico analysis was applied to four other Paratrichodorus spp. and seven Trichodorus spp. to predict the primer specificity according to the sequence information in the GenBank database. Previously, in silico analysis has been used for primer specificity prediction in molecular diagnostics of plant disease pathogens, such as Pythium root rot (Pythium spp.) (Schroeder et al. 2006), Rhizoctonia root rot (Rhizoctonia solani and $R$. oryzae) (Okubara et al. 2008), Xanthomonas citri pv. citri (Delcourt et al. 2013), root lesion nematodes (Pratylenchus thornei and P. neglectus) (Yan et al. 2012, 2008, 2013b), and cereal cyst nematode (Heterodera filipjevi and $H$. avenae) (Yan et al. 2013a). Our in silico analysis for Paratrichodorus allius primer specificity evaluation suggested that primers PaF11 and PaR12 were highly specific to $P$. allius but not to another 13 stubby root nematode species. The results of actual experimental PCR were consistent with the predictions obtained from in silico analysis, revealing that this primer set is specific to $P$. allius and can be successfully used in both conventional and real-time PCR assays to detect and identify this nematode species from a set of plant-parasitic nematodes species including other stubby root ( $P$. porosus, $P$. minor, and $T$. obtusus), cyst (Heterodera, Cactodera, and Globodera spp.), root-knot, root lesion, spiral, pin, lance (Hoplolaimus spp.), dagger (Xiphinema spp.), stunt, and ring nematodes. The developed PCR assays identified $P$. allius from 18 populations of stubby root nematodes from a range of fields on various crops and 11 nematode communities comprising stubby root nematodes, other common plant-parasitic nematodes, and nematodes that are not plant parasites. Despite the diversity present among populations, the sequence information of the D2-D3 segment of $28 \mathrm{~S}$ rDNA or ITS1 rDNA and morphometric measurements confirmed the accuracy of the PCR diagnostic results. Compared with previous studies on stubby root nematode species identification using nematode individuals (Boutsika et al. 2004a,b; Duarte et al. 2011; Holeva et al. 2006; Kumari and Subbotin 2012; Riga et al. 2007), our developed conventional PCR assay could be used to identify $P$. allius from a complex nematode community harboring other plantparasitic nematodes and free-living nematodes. The ability to detect and identify $P$. allius directly from soil-extracted DNA will be tested in the future to facilitate the use of the assay under a broader range of diagnostic scenarios.

It is noted that the designed primer set in this study can be used not only in a conventional PCR assay but also in a SYBR-based real-time PCR assay. The advantages of real-time PCR assay are higher sensitivity and better specificity, and the ability to quantify target nematode DNA. Compared with conventional PCR techniques, real-time PCR provides immediate results that are expressed by $\mathrm{Cq}$ value without the need of agarose gel electrophoresis. Currently, most stubby root nematodes species are identified by microscopic observation, morphological measurements, and DNA sequencing (Heydari et al. 2014a,b; Lopez-Nicora et al. 2014; Riga and Neilson 2005; Yan et al. 2016a, b; Ye et al. 2015). One prior study in the United Kingdom reported identification and quantification of two other stubby root nematode species ( $P$. pachydermus and T. similis) using a TaqMan-based realtime PCR assay (Holeva et al. 2006). However, their study did not include $P$. allius, a prevalent vector of the TRV that causes corky ringspot disease of potato, an issue of significant economic importance to potato production in the United States. When used with DNA extracted from isolated nematodes, our SYBR-based real-time PCR protocol allowed the detection and identification of $P$. allius populations in a very sensitive manner. It was shown that as little as $1.92 \times 10^{-4} \mathrm{ng}$ of template DNA could be detected. The sensitivity of our realtime PCR assay was comparable with similar qPCR methods of plant-parasitic nematode detection. It was reported that root-lesion nematode $P$. thornei was detectable from $8.25 \times 10^{-2}$ ng of DNA (Yan et al. 2012). It was also found that, even though all DNA samples used for the experiment of $P$. allius detection in Table 1 were extracted from single nematodes, $\mathrm{Cq}$ values displayed significant variation among DNA extracts $(18.9 \pm 0.0$ to $27.5 \pm 0.1)$. This could be explained by variation in the DNA extraction among samples, different life stages of nematodes used for DNA extraction (Sato et al. 2007), or the degradation of DNA due to frequent freeze-thaw cycles, because DNA were not extracted at the same time and some of them were used multiple times (Röder et al. 2010; Tondella et al. 2002).

Rather than using DNA extracts of single nematodes for $P$. allius detection and identification, our developed PCR assays were also evaluated using DNA extracts of nematode communities isolated from infested fields in North Dakota containing stubby root nematodes, other plant-parasitic nematodes, and nematodes that are not plant parasites. It was observed that the conventional PCR successfully detected $P$. allius from all nematode communities harboring $P$. allius using both a modified PCI method and a commercial kit for DNA extraction. The real-time PCR detected target nematodes from nematode communities using DNA extracted by a commercial DNA extraction kit. It indicates that the potential capability of our developed assays on $P$. allius detection from DNA extracted from soil 
that may be explored in the future. However, the real-time PCR did not generate $\mathrm{Cq}$ values due to the disorganized fluorescence signal when using DNA extracted from nematode communities by the modified PCI method. It was observed under the microscope that not only nematodes but also tiny soil particles, plant tissues, mites, amoeba, and larva of other insects were present in the nematode suspensions. Therefore, the DNA extracted from nematode suspensions were not pure enough for use in real-time PCR because, overall, real-time PCR is more sensitive to such contaminants than conventional PCR. Additional DNA purification steps may be needed to detect $P$. allius from nematode communities for the real-time PCR assay if using the PCI DNA extraction method.

PCR assays with species-specific primers exploited in this study provide a rapid and reliable detection and identification of $P$. allius from single nematodes and from nematode communities. Additionally, the PCR assays did not require a secondary step the way other nematode PCR diagnostic strategies did, such as PCR-RFLP (Duarte et al. 2011; Kumari and Subbotin 2012). Conventional PCR provides a less expensive assay, has fewer technical requirements, and can rapidly process large amounts of samples in a routine diagnosis of this nematode. The developed real-time PCR method could satisfy a higher requirement of sample diagnosis such as quantitative detection of this nematode that may be beneficial for making planting and nematode control decisions. With further optimization, our real-time PCR assays may be adopted for future use in direct detection, identification, and quantification of this nematode from soil samples, simplifying the diagnosis process by avoiding nematode extraction, identification, and counting.

\section{Acknowledgments}

This research was supported by United States Department of AgricultureNational Institute of Food and Agriculture Special Crop Research Initiative, Sugarbeet Research and Education Board of Minnesota and North Dakota, North Dakota Soybean Council, North Dakota Corn Council, and North Dakota Department of Agriculture. We thank A. Plaisance, A. Upadhaya, and I. Chowdhury for collecting nematodes and growers who allowed us to collect soil samples from their properties; and P. Agudelo from Clemson University, B. Crow from the University of Florida, W. Ye from the North Carolina Department of Agriculture \& Consumer Services, and D. Smiley at Oregon State University for providing nematodes or DNA of control species.

\section{Literature Cited}

Boutsika, K., Brown, D. J. F., Philips, M. S., and Blok, V. C. 2004a. Molecular characterization of the ribosomal DNA of Paratrichodorus macrostylus, $P$. pachydermus, Trichodorus primitivus and $T$. similis (Nematoda: Trichodoridae). Nematology 6:641-654

Boutsika, K., Phillips, M. S., MacFarlane, S. A., Brown, D. J. F., Holeva, R. C., and Blok, V. C. 2004b. Molecular diagnostics of some trichodorid nematodes and associated Tobacco rattle virus. Plant Pathol. 53:110-116.

Cherry, T., Szalanski, A. T., Todd, T. C., and Powers, T. O. 1997. The internal transcribed spacer region of Belonolaimus (Nemata: Belonolaimidae). J. Nematol. 29:23-29.

Decraemer, W. 1995. The Family Trichodoridae: Stubby Root and Virus Vector Nematodes. Kluwer Academic Publishers, Boston.

Decraemer, W., and Baujard, P. 1998. A polytomous key for the identification of species of the family Trichodoridea Thorne, 1935 (Nematoda: Triplonchida). Fundam. Nematol. 21:37-62.

Decraemer, W., and Robbins, R. T. 2007. The who, what and where of Longidoridae and Trichodoridae. J. Nematol. 39:295-297.

Delcourt, S., Vernière, C., Boyer, C., Pruvost, O., Hostachy, B., and RobèneSoustrade, I. 2013. Revisiting the specificity of PCR primers for diagnostics of Xanthomonas citri pv. citri by experimental and in silico analyses. Plant Dis. 97:373-378.

Donn, S., Griffiths, B. S., Neilson, R., and Daniell, T. J. 2008. DNA extraction from soil nematodes for multi-sample community studies. Appl. Soil Ecol. 38:20-26.

Duarte, I. M., Almeida, M. T. M., Duarte, M. M., Brown, D. J. F., and Neilson, R. 2011. Molecular diagnosis of trichodorid species from Portugal. Plant Pathol. 60:586-594.

Fatima, F., Chaudhary, I., Ali, J., Rastogi, S., and Pathak, N. 2011. Microbial DNA extraction from soil by different methods and its PCR amplification. Biochem. Cell Arch. 11:85-90.

Heydari, R., Tanha Maafi, Z., and Decraemer, W. 2014a. Morphological and molecular characterization of Trichodorus golestanensis (Nematoda: Trichodoridae), a new species from Iran. Eur. J. Plant Pathol. 140:329-340.
Heydari, R., Tanha Maafi, Z., Omati, F., and Decraemer, W. 2014b. First report of stubby root nematode, Paratrichodorus teres (Nematoda: Trichodoridae) from Iran. Australas. Plant Dis. Notes 9:131-133.

Holeva, R., Phillips, M. S., Neilson, R., Brown, D. J. F., Young, V., Boutsika, K. and Blok, V. C. 2006. Real-time PCR detection and quantification of vector trichodorid nematodes and Tobacco rattle virus. Mol. Cell. Probes 20:203-211.

Ingham, R. E., Hamm, P. B., Williams, R. E., and Swanson, W. H. 2000. Control of Paratrichodorus allius and corky ringspot disease of potato in the Columbia Basin of Oregon. J. Nematol. 32:566-575.

Jenkins, W. R. 1964. A rapid centrifugal-flotation technique for separating nematodes from soil. Plant Dis. Rep. 48:692.

Kumari, S., and Subbotin, S. A. 2012. Molecular characterization and diagnostic of stubby root and virus vector nematodes of the family Trichodoridae (Nematoda: Triplonchida) using ribosomal RAN genes. Plant Pathol. 61: 1021-1031.

Lopez-Nicora, H. D., Mekete, T., Sekora, N., and Niblack, T. L. 2014. First report of the stubby-root nematode (Paratrichodorus allius) from a corn field in Ohio. Plant Dis. 98:1164.

Mojtahedi, H., and Santo, G. S. 1999. Ecology of Paratrichodorus allius and its relationship to the corky ring-spot disease of potato in the Pacific Northwest. Am. J. Potato Res. 76:273-280.

Okubara, P. A., Schroeder, K. L., and Paulitz, T. C. 2008. Identification and quantification of Rhizoctonia solani and $R$. oryzae using real-time polymerase chain reaction. Phytopathology 98:837-847.

Plaisance, A., and Yan, G. P. 2015. Comparison of two nematode extraction techniques. J. Nematol. 47:263-264.

Ploeg, A. T., and Decraemer, W. 1997. The occurrence and distribution of trichodorid nematodes and associated tobraviruses in Europe. Nematologica 43:228-251.

Riga, E., Karanastasi, E., Oliveira, C. M. G., and Neilson, R. 2007. Molecular identification of two stubby root nematode species. Am. J. Potato Res. 84:161-167.

Riga, E., and Neilson, R. 2005. First report of the stubby-root nematode, Paratrichodorus teres, from potato in the Columbia Basin of Washington State. Plant Dis. 89:1361.

Röder, B., Frühwirth, K., Vogl, C., Wagner, M., and Rossmanith, P. 2010. Impact of long-term storage on the stability of standard DNA for nucleic acid based methods. J. Clin. Microbiol. 48:4260-4262.

Sato, E., Min, Y. Y., Shirakashi, T., Wada, S., and Toyota, K. 2007. Detection of the root-lesion nematode, Pratylenchus penetrans (Cobb), in a nematode community using real-time PCR. Jpn. J. Nematol. 37:87-92.

Schroeder, K. L., Okubara, P. A., Tambong, J. T., Lévesque, C. A., and Paulitz, T. C. 2006. Identification and quantification of pathogenic Pythium spp. from soils in eastern Washington using real-time polymerase chain reaction. Phytopathology 96:637-647.

Subbotin, S. A., Ragsdale, E. J., Mullens, T., Roberts, P. A., Mundo-Ocampo, M. and Baldwin, J. G. 2008. A phylogenetic framework for root lesion nematodes of the genus Pratylenchus (Nematoda): Evidence from 18S and D2-D3 expansion segments of $28 \mathrm{~S}$ ribosomal RNA genes and morphological characters. Mol. Phylogenet. Evol. 48:491-505.

Tanha Maafi, Z., Subbotin, S. A., and Moens, M. 2003. Molecular identification of cyst-forming nematodes (Heteroderidae) from Iran and a phylogeny based on the ITS sequences of rDNA. Nematology 5:99-111.

Tondella, M. L. C., Talkington, D. F., Holloway, B. P., Dowell, S. F., Cowley, K., Soriano-Gabarro, M., Elkind, M. S., and Fields, B. S. 2002. Development and evaluation of real-time PCR-based fluorescence assays for detection of Chlamydia pneumoniae. J. Clin. Microbiol. 40:575-583.

Van Hoof, H. A. 1964. Serial transmission of rattle virus by a single make of Trichodorus pachydermus Seihorst. Nematologica 10:141-144.

Yan, G. P., Khan, M. F., Huang, D., Lai, X., and Handoo, Z. A. 2016a. First report of the stubby root nematode Paratrichodorus allius on sugar beet in Minnesota. Plant Dis. 100:1022.

Yan, G. P., Plaisance, A., Huang, D., Upadhaya, A., Gudmestad, N. C., and Handoo, Z. A. 2016b. First report of the stubby root nematode Paratrichodorus allius on potato in North Dakota. Plant Dis. 100:1247.

Yan, G. P., Plaisance, A., and Ye, W. 2015. Plant-parasitic nematodes on field crops in southeastern and northeastern North Dakota. (Abstr.) Phytopathology 105:S4.153.

Yan, G. P., Smiley, R. W., and Okubara, P. A. 2012. Detection and quantification of Pratylenchus thornei in DNA extracted from soil using real-time PCR. Phytopathology 102:14-22.

Yan, G. P., Smiley, R. W., Okubara, P. A., and Skantar, A. M. 2013a. Speciesspecific PCR assay for differentiating Heterodera filipjevi and $H$. avenae. Plant Dis. 97:1611-1619.

Yan, G. P., Smiley, R. W., Okubara, P. A., Skantar, A. M., Easley, S. A., Sheedy, J. G., and Thompson, A. L. 2008. Detection and discrimination of Pratylenchus neglectus and P. thornei in DNA extracts from soil. Plant Dis. 92:1480-1487.

Yan, G. P., Smiley, R. W., Okubara, P. A., Skantar, A. M., and Reardon, C. L. 2013b. Developing a real-time PCR assay for detection and quantification of Pratylenchus neglectus in soil. Plant Dis. 97:757-764.

Ye, W., Zeng, Y., and Kerns, J. 2015. First report of Trichodorus obtusus on turfgrass in North Carolina, U.S.A. Plant Dis. 99:291. 